Research Article

Paolo Bravi, Teresa Proto*

\title{
Intra-line and inter-individual variation in Sardinian arrepentina
}

https://doi.org/10.1515/opli-2019-0027

Received September 15, 2018; accepted June 18, 2019

\begin{abstract}
S'arrepentina is a genre of extemporary poetry performed by semi-professional poets, both at informal gatherings and in public contests in south-central Sardinia. The name arrepentina refers both to the genre/performance in its entirety, and to the set of metrical forms and rhyme schemes used during the performance. Lines occur in non-strophic (stichic) form, and are made up of halflines linked by a complex system of rhymes. Unlike similar metrical forms, s'arrepentina is not performed in a "free rhythm" singing style. Typically, poets improvise their verses accompanied by an accordion, which provides a steady pulse. In this study, we investigate variation in nine arrepentinas and we aim to determine the degree of rhythmical variability in each halfline by measuring it against the underlying meter provided by the musical accompaniment. From the analysis, it emerges that the rhythmical variants are concentrated at specific positions, and their distribution suggests an asymmetry between the two halflines. Some inter-individual variation among the poets also appears in their preference for one type of variant over others.
\end{abstract}

Keywords: arrepentina, extemporary poetry, musical halfline, verbal halfline, asymmetric setting, microvariation

\section{Introduction}

S'arrepentina is a genre of extemporary poetry performed by semi-professional poets, both at informal gatherings and in public contests. These performances are found in south-central Sardinia (see Fig. 1), and the language employed by the poets is the variety of Campidanese in use in the central part of the island (Murgia 2012). Typically, poets improvise their verses accompanied by an accordion, which provides a steady pulse throughout the whole performance.

The name arrepentina ${ }^{1}$ can be used to refer to three (related) entities: a) the poetic genre/contest as a whole; b) the set of metrical forms and rhyme schemes used for the main parts of the performance (namely a sa dereta ['in a direct way'], riepilogada ['repeated lines'] and arretrogada ['line repetition with changed word order'] with its various subtypes); ${ }^{2}$ and c) each of the turns in which poets improvise using those metrical/rhyme schemes, followed by a "coda" section in the metrical scheme known as currentina (see

1 The denomination makes reference to the dimension of improvisation (the Latin adjective rĕpentīnus means "improvised, unexpected, with a short-time effect"). Similarly, in Cuba, the term repentismo generally refers to the phenomenon of poetic improvisation (see Diaz-Pimienta 1998), which points to historically documented links between Sardinian and Spanish poetry (see Garzia 1916, Porcu 2008). Some basic notes on the early development of the poetic genre of improvised poetry currently known as repentina or arrepentina can be found in Ghiani 1994a and 1994b. The etymology of the word within the context of Sardinian poetry, however, remains to be thoroughly investigated.

2 For an introductory but not exhaustive account of these rhyme schemes: see Lutzu 2007, Lutzu \& Murru 2012.

*Corresponding author: Teresa Proto, Leiden University, Leiden, Netherlands, E-mail: teresa.proto@gmail.com

Paolo Bravi, Martin Behaim Gymnasium, Nuremberg, Germany 


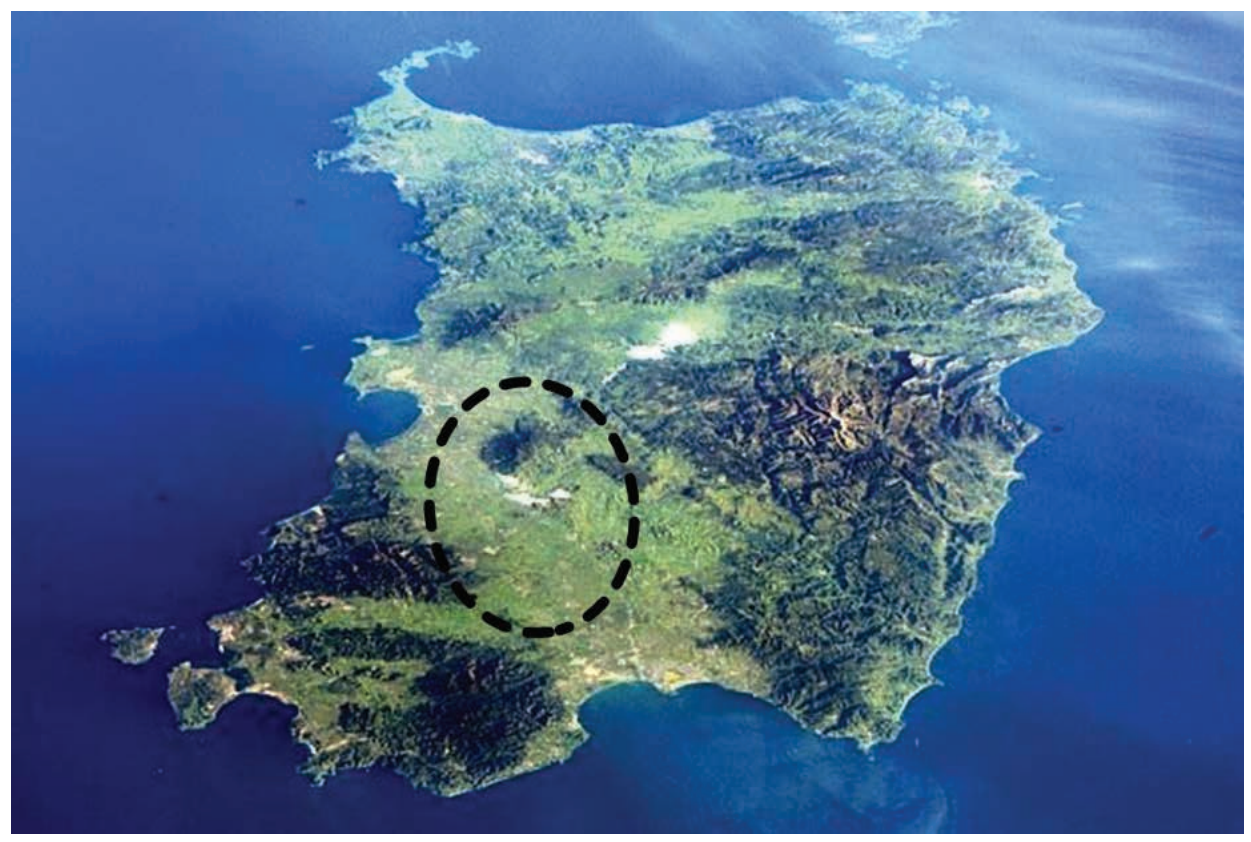

Figure 1: Area of diffusion of the practice of improvised poetry in the a s'arrepentina style

infra). In this paper, we will use the general term "contest" in relation to a); AMS (arrepentina as a set of metrical schemes) when referring to b); and APF (arrepentina as poetic form) to denote each turn as defined in c).

A contest in the arrepentina genre is divided into sections, each characterized by the use of specific metrical forms and the discussion of one theme (tema) in which each poet defends one viewpoint (see Table 1, adapted from Lutzu 2007: 10 and Lutzu \& Murru 2012: 157). Within this macrostructure, the metrical form arrepentina occurs at three different moments (Table 1, in bold). This means that in the course of one contest, each poet has at least three opportunities to improvise using the schemes proper to this metrical form. In this paper, the analysis is limited to the APFs occurring within the tema section.

Each arrepentina (APF) displays a stichic (non-strophic) form with a variable number of lines, which can be broken down into halflines linked by a complex system of rhymes. Each arrepentina (APF) is constituted by one AMS section followed by a coda in the currentina form, which comprises an indefinite number of lines linked by AB rhyme throughout, as illustrated in Fig. 2. Each line of the currentina could be divided into two halflines; however, unlike in the AMS, there is no internal rhyme.

Previous studies devoted to arrepentina (Lutzu 2007; Murru 2010; Lutzu \& Murru 2012) consider the line either as "double", i.e. as made up of a pair of halflines, or as a couplet, whereby the two halflines are

Table 1: Structure of the poetic contest

\begin{tabular}{|c|c|c|}
\hline SECTION & METRICAL FORM & THEME \\
\hline $\begin{array}{l}\text { Ingressu } \\
\text { or esòrdiu }\end{array}$ & $\begin{array}{l}\text { Mutetu } \\
\text { Currentina } \\
\text { Arrepentina }\end{array}$ & $\begin{array}{l}\text { free } \\
\text { (greetings and thanks) }\end{array}$ \\
\hline $\begin{array}{l}\text { Tema } \\
\text { (a contrasto) }\end{array}$ & $\begin{array}{l}\text { Currentina } \\
\text { Arrepentina }\end{array}$ & set by the committee \\
\hline Duinas & Duinas & $\begin{array}{l}\text { free } \\
\text { (with reference to theme) }\end{array}$ \\
\hline Finali & $\begin{array}{l}\text { Currentina } \\
\text { Arrepentina }\end{array}$ & $\begin{array}{l}\text { free } \\
\text { (greetings and thanks) }\end{array}$ \\
\hline
\end{tabular}




$\begin{array}{ll}\text { Divertimentu po tui } & \text { Ma sa terra gi est bella } \\ \text { E ddi fazzu sentinella } & \text { Ca no ponit imbarazzu } \\ \text { Sentinella ddi fazzu } & \text { Però ch'est terra puru sa luna } \\ \text { Chi teneus fortuna } & \text { Ei s'aggiudas Deus } \\ \text { Chi fortunas teneus } & \text { De ddu azziai }\end{array}$

Toccat a nos(u) puru s'indirizza su passau

Ca prima fuant(a) cosas de no podi toccai

Invece a sa scienza si dona provau

Ca finza pei in sa luna ant deppiu piazzai

Una bandiera finzas si (n)c’ant(i) prantau

Figure 2: Transition from the AMS section (ending with De ddu azziai) to the currentina coda (starting with Toccat) in one APF improvised by the poet Remo Orrù, as transcribed in Rossi \& Meloni 2007: 555 (translation: Fun for you / But the earth is beautiful // And I am a guard of it / Even if the moon is soil as well // If we are lucky / And God help us // If luck we have / To get to it // It is up to us to also address the past // Because previously there were things one may not touch // Instead science gives us proof // That even on the moon they have set foot // And even a flag they have planted on it).

graphically represented on separate lines (see Masili 1995; Zedda \& Pani 2005: 18). ${ }^{3}$ The former interpretation is based on various arguments, the most relevant ones being (i) the presence, within the macrostructure, of the section named currentina, in which the rhyme scheme only involves the second halfline; (ii) the analogies between arrepentina and similar poetic traditions of Sardinia, namely the cantzoni a curba (Madau 1997 ed. or. 1787: 57, Fadda Pischedda 1895, Pillai 1985, Bravi 2012a); and (iii) the fact that the two halflines are set - consistently, though not exclusively - to a melody comprising a unitary melodic curve. ${ }^{4}$ In line with the approach adopted in the most recent literature, in this study we opt for this interpretation and will consider the line as comprising two sub-units, which will interchangeably be called "halfline" or "hemistich".

It has been observed that the length of the halflines varies between seven and nine syllables in the arrepentina (Onnis 1997: 36). On the basis of this observation, it has been claimed that the basic underlying meter is either a settenario, i.e. a seven-syllable line with the last stressed syllable in the sixth position (Zedda \& Pani 2005: 18, Cirese et al. 2006: 35), or an ottonario, i.e. an eight-syllable line with the last stressed syllable in the seventh position (Lutzu 2007)..$^{5}$

One source for the observed variability in the syllable count lies in the syllabification rules that take place in versification. In the Sardinian poetry, as in other Romance poetic traditions, adjacent vowels at the juncture between syllables/words may be merged into one metrical position thanks to "syllabification" processes such as synaeresis, synaloepha, etc. (Fabb 2002: 9). Conversely, any syllable containing two vowel sounds in its nucleus, i.e. a diphthong, may be split into two syllables to fit the meter. ${ }^{6} \mathrm{~A}$ further source of variability lies in the phonology of the language. Sardinian allows for the use of a "paragogic

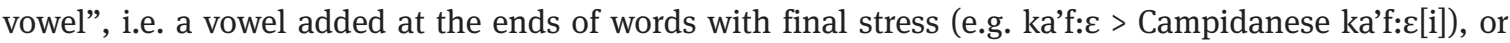

3 On the structure of the Doppelvers, see Elwert 1987, 78-82. With reference to the Sardinian metrical tradition, see Spano 1840: 11-14, Piras 2012.

4 Similar arguments are evoked in support of the second interpretation, namely (i) similarity with other poetic forms (especially the cantada or longarina) and (ii) the representation - in graphic as well as mental form - that is reported by the poets themselves.

5 For the notion of "metrical position" in the area of metrical studies, refer to Halle \& Keyser 1966: 417, Di Girolamo 1976: 22-24, Ramous 1984: 205, Beltrami 1991: 39-40. In the present study, we use "metrical position” to refer solely to the meter underlying the text, not the music.

6 For issues relating to metrical scansion and adjacent vowels, see Elwert 1987: 6-30, Beltrami 1991: 22-25; for these issues within the Sardinian poetic tradition, see Bravi 2010: 463. The tendency to split diphthongs into two syllables is even stronger in Sardinian than in Italian, where diphthongs usually comprise a full vowel followed or preceded by a glide. In Sardinian, glides play a minor role and it is common to find a sequence of two full vowels in place of a diphthong. This tendency of the language is of course reflected in poetry. 
words with penultimate/antepenultimate stress ending in a consonant (e.g. 'bal:az > 'bal:az[a]; 'mendulaz $>$ 'mendulaz[a]).7 The relevance of the paragogic vowel for purposes of metrical scansion is not always clear (in the case of words like ka'f: $\varepsilon[i]$ ), and its effects in poetry have received little attention in the literature.8 Another typical feature of Campidanese Sardinian is the drop of the nasal [n] in intervocalic position, with subsequent nasalization of the (preceding) vowel.9 Whether both vowels keep their syllabicity or merge into one syllable (= one metrical position) is difficult to establish on the basis of a written text.

All phenomena mentioned above affect the metrical scansion of a number of lines and make it difficult to determine what the underlying meter is, especially if one relies on written sources for the analysis, e.g. poetry collections, transcriptions of poetic contests etc. In this study, we refrain from using written sources, and base our analysis on the recording of a live performance, including both the textual and musical elements involved in the rendering of the arrepentina. As the object of our investigation is sung poetry, we will approach it using the framework of isochronous metrics (Cornulier 2000). Our goal is to determine the degree of rhythmical variability in each halfline by measuring it against the underlying meter provided by the musical accompaniment. ${ }^{10}$ In fact, the (more or less) isochronous pulse maintained by the accordion provides a sort of structural and perceptual "grid" on which the verbal text is improvised on the basis of patterns that are not arbitrary, but fairly predictable. From the analysis, it emerges that the rhythmical variations are concentrated in specific positions of the grid, and the distribution of the variants suggests an asymmetry between the two halflines. It also appears that there is some inter-individual variation among the poets in their preference for one type of variant over others.

\section{Meter and tempo of the instrumental accompaniment}

During the contest, poets are accompanied by an accordionist who plays a simple sequence of chords modulated on the basis of the melody proper to each poet. The accompaniment of the accordion provides a steady and fairly regular pulse throughout the performance. This regularity, however, is only relative. Within each turn of arrepentina (APF), the pulse usually undergoes an appreciable, progressive acceleration. This is shown in the diagram in Figure 3, which is based on the automatic detection of the occurrence of the note onsets as it has been extracted from the recording of the sound given out by the keyboard of the lowpitched sounds. This diagram depicts the general progression of tempo across the nine arrepentinas under investigation. ${ }^{11}$

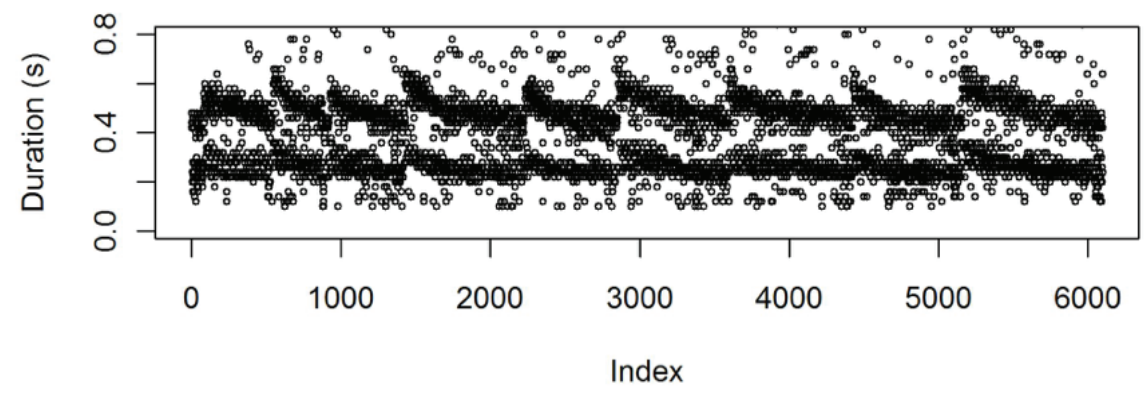

Figure 3: Time intervals occurring between the onsets of the notes generated by the accordion's keyboard of low-pitched sounds. On the $\mathrm{x}$-axis, the index of the onset notes performed by the bass section of the accordion; on the $y$-axis, the IOI (inter-onset-interval) between each note onset and the following, expressed in seconds. The bass notes offer strong evidence of the binary rhythmic trend of the performance.

7 The insertion of a paragogic vowel is a well-known phenomenon of Sardinian (Virdis 1978, par. 14, Contini 1987, 462-468). 8 Some preliminary observations are in Bravi 2010: 465 and - with specific reference to the arrepentina - in Lutzu 2007: 24.

9 On intervocalic nasal and its effects on meter, see Contini 1987: 135-136, Lutzu 2007: 24 and Puddu 2008: 45.

10 In line with this principle, halflines in our corpus were numbered on the basis of their occurrence within the performance (as already in Lutzu 2007), and acknowledging that the first and second halflines usually correspond to distinct rhythmicalmelodic profiles, although variation is possible in this respect as well.

11 The diagram was hosted on the website www.sardinianoralpoetry.net - see infra, footnote 12 - under the section Arrepentina $>$ Voci > Ritmo. See also Bravi 2012b. 
The binary subdivision of the musical meter is evident in the parallelism of the two areas of rhythmical values. These values are concentrated in nine sections, which correspond to the nine turns taken by the three poets. For each turn/section, a slope is visible in the diagram, which represents the progressive temporal acceleration detected for each poet during each turn.

\section{Corpus and methodology}

Our corpus is based on the recording of a public performance held at Gonnosfanadiga (Cagliari) in $2011 .^{12}$ The contest featured three eminent poets: Alberto Atzori, Giuseppe Caddeu and Efisio Caddeo depicted in Fig. 4 and henceforth referred to, respectively, as AA, CG and CE.

The recording was carried out using separate tracks for the voices of the poets (one microphone/channel) and the accordion (two microphones/channel, one mic for each of the two keyboards of the instrument). The total duration of the nine arrepentinas extracted from the recording amounts to 38 minutes and 50 seconds.

The recording was later analyzed using Praat (Boersma \& Weenink 1992-2018). The audio file for each arrepentina was segmented and annotated in a textgrid with various (interval) tiers, corresponding to the following (see Fig. 5): [1] orthographic transcription of each halfline; [2] phonetic transcription of each sound

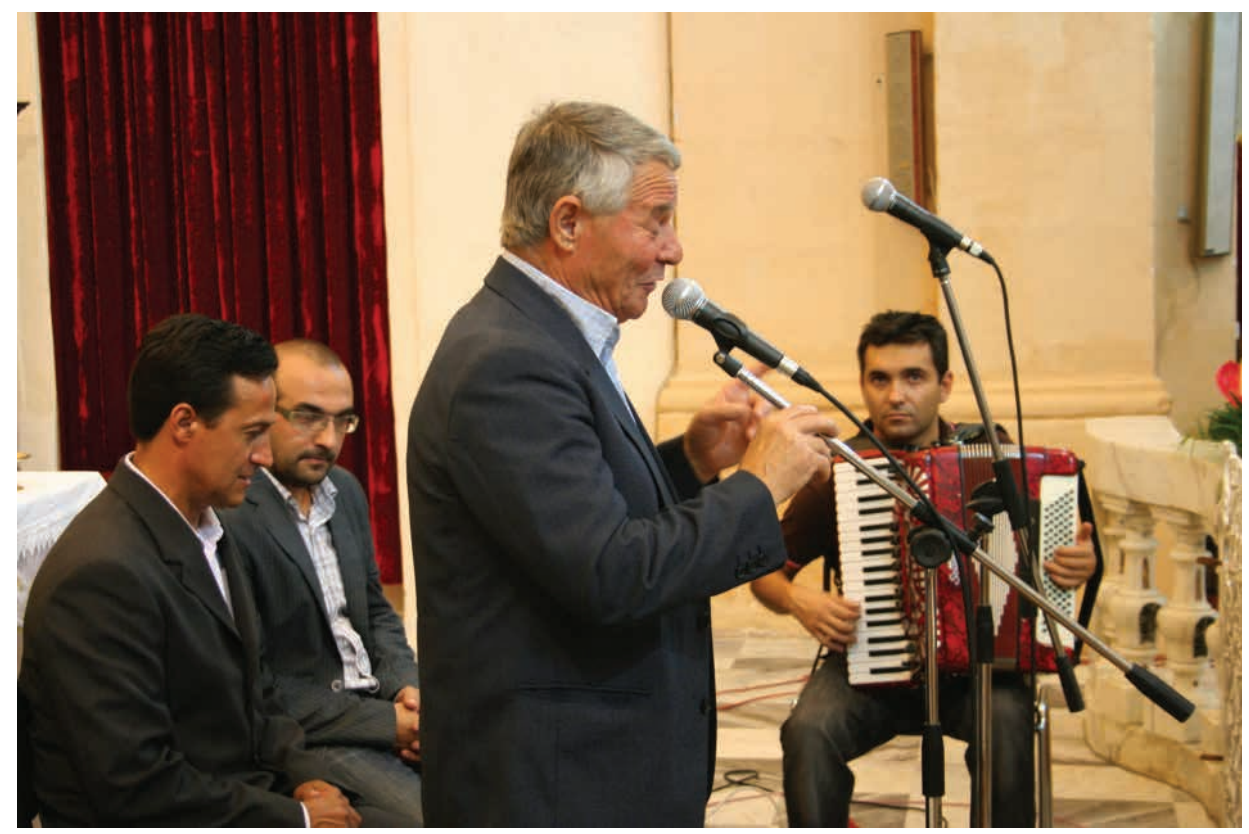

Figure 4: The performance held at Gonnosfanadiga, 3 September 2011 (photo by PB). The improvising poet Efisio Caddeo is singing, accompanied by Gianfranco Massa (accordion). Giuseppe Caddeu (seated, left) and Alberto Atzori (seated, right) are planning while waiting for their turn.

12 Our corpus was compiled in 2011 within the framework of a project funded by the Provincia di Cagliari, Assessorato alla Cultura, and the Conservatorium of Music "E. Porrino" in Cagliari. The research project - which comprised the recording of a poetic contest, the collection of general information on the improvised poetry a s'arrepentina, interviews with the poets and the organizers of the contest, a transcription and a textual as well as musical analysis of the performance - was conducted by Paolo Bravi (co-author of the present paper) together with Marco Lutzu, Ignazio Macchiarella, Roberto Milleddu and Ignazio Murru. The documents produced in the framework of that research project used to be available on the website www.sardinianoralpoetry. net, which is offline at present. The video recordings of the poetic duel, however, are still available on the YouTube channel SardinianOralPoetry, which was made to complement the website. The recording of the main section of the poetry contest, which constitutes the object of the present study, can be found at: https://www.youtube.com/watch?v=N3PiZQ9GJTc\&list=RDN 3PiZQ9GJTc\&start_radio=1. With the permission of the co-investigators, the original materials have been used for the aims of the analysis presented here. 
segment (vowels as well as consonants); [3] V-to-V (vowel-to-vowel) intervals; [4] musical transcription of the rhythmic values, i.e. durations, coded as explained below; and [5] metrical positions corresponding to the intervocalic intervals. ${ }^{13}$

The choice of segmenting the text into intervocalic intervals instead of syllables was motivated on the basis of two arguments. Firstly, the V-to-V interval has long been employed as a measure of rhythmic isochrony in speech (Farnetani \& Kori 1986, Janker 1996, Barbosa et al. 2005, Pettorino et al. 2015) as well as in music (List 1974, Adamo 1994, Cornulier 2000, Bravi 2015). Secondly, using this parameter prevents us from conceiving the structure of the lines in terms of a putative (iso)syllabism, and allows us to overcome some of the above-mentioned issues concerning the metrical scansion. By aligning the spoken intervals with the musical intervals, we benefit from a scansion that is the same for all lines and all poets in the corpus and are able to consider the (half)line in its integrity, i.e. as a combination of text and music. Our approach further allows us to classify the effects of syllabification processes, paragogic vowels and nasal drop mentioned in the previous section in an objective way. ${ }^{14}$

S'arrepentina is a form of extemporary, sung poetry. This entails that poets not only improvise their lines, as is the case in slam poetry, but actually sing them. Each poet, in fact, improvises using a melody that is recognizable as part of his individual style, but is also fairly traditional. ${ }^{15}$ As in other European vocal folk traditions (see Brăiloiu 1982), the rhythm of the arrepentina is based essentially on two values, which we identify as the quarter note and the eighth note. In the textgrid, these durations are annotated with the symbols $q$ (= quarter note) and $e$ (= eighth note) (see Figure 5, tier 4). Occasionally, these values can

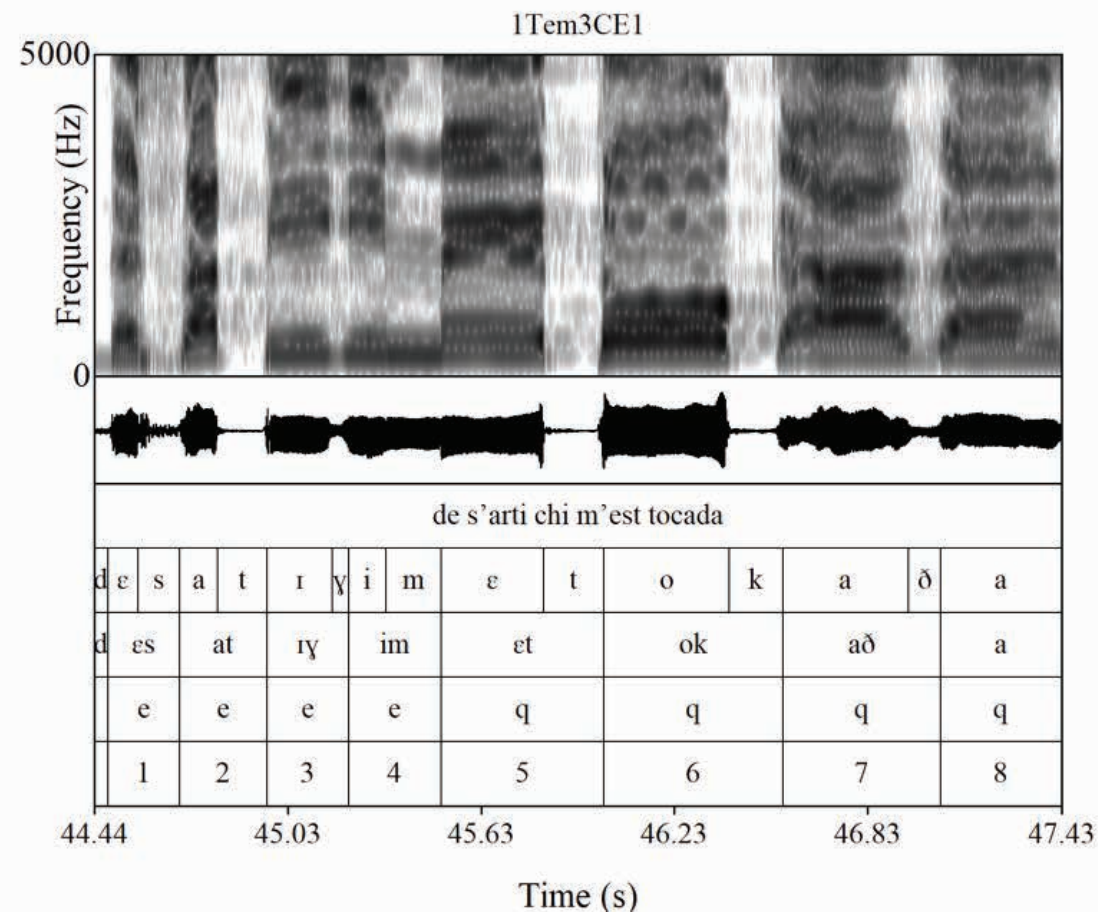

Figure 5: An example of an annotated halfline. From top to bottom: [1] orthographic transcription; [2] broad phonetic transcription; [3] V-to-V intervals; [4] musical transcription (durations); [5] metrical positions. In the panel above is the broad-band spectrogram with the waveform of the corresponding audio excerpt.

13 The annotation also included other tiers; specifically, the different levels of relative prominence in each linguistic string and in each musical measure were annotated. These further levels, although pertinent for the metrical representation of the individual syllables/V-to-V intervals, are not directly relevant for the purposes of the present study and therefore not included in the figures.

14 The details of the epistemology of the arrepetina form the object of a separate study, currently submitted for publication.

15 A thorough examination from the musical perspective of the characteristics and the variability of the two melodic phrases has not been conducted so far. Some basic observations and transcriptions can be found in Lutzu 2007, Murru 2010, Bravi 2012b and Bravi \& Proto (submitted for publication). 
surface as a dotted quarter note $(q \cdot)$ or as a half note ( $h=$ half note), depending on whether the basic quarter duration is exceeded by one eighth note or by a quarter note. However, no duration is shorter than the eighth note, with rare exceptions that could be classified as 'errors' in the planning and delivery of the line. ${ }^{16}$ The rhythmical values toward the end of the line may be accompanied by the phonetic symbol for lengthening (:) to indicate that the preceding duration is not rigidly definable. On tier 5 , the corresponding metrical positions are notated with a numbering that goes from 1 to 8. Being based on V-to-V intervals, the metrical positions indicated here only partially overlap with the eight syllables identified by our predecessors.

As a matter of fact, s'arrepentina is not performed in a "free rhythm" singing style. The rhythmic pulse ${ }^{17}$ is recognizable both in the instrumental accompaniment and, most importantly, in the singing. It is this pulse that we have used as a baseline of reference to determine whether, for instance, a diphthong is to be split into two syllables falling into two distinct metrical positions. Likewise, we have used the pulse positions to extract the (musical) rhythmical pattern underlying each halfline. By doing so, we have identified two patterns, which are implemented differently in the two verbal halflines. In order to investigate the relation between the verbal (or textual) halflines and the rhythmic structure intrinsic to the melody, we therefore need to distinguish the verbal from the musical halflines, both conceptually and empirically. While the two verbal halflines will be named $\mathrm{HL}_{1}$ and $\mathrm{HL}_{2}$, respectively, we will use "musical phrase" to refer to the individual rhythmic units in which the melodic line can be broken down. The "melodic line" is conceived of as the parallel of the "line" at the musical level.

\section{Variation in the pairing of verbal halflines and musical phrases}

On the outermost level - i.e., the level that has the major effect on improvisation - one relevant factor of variation is the matching between verbal hemistichs and two partially different musical phrases, henceforth named MPa and MPb, respectively. ${ }^{18}$ An exhaustive description of the melodic features of the two musical phrases performed by each improvising poet is not a primary concern of the present paper, and is a topic that deserves separate attention. However, a broad overview is presented here, together with some illustrations and relevant captions (Fig. 6 and 7). Figure 6 shows the distribution of the fundamental frequencies and the melodic profiles of the two melodic phrases performed by the three poets in the improvised context under examination. There are common aspects between $\mathrm{MPa}$ and $\mathrm{MPb}$. Even without taking into account melodic factors, such as the andamento or the distribution of intervals, it appears that both musical phrases share the same melodic range - one fifth - and the same scale structure, comprising the first five degrees of the major scale. At the same time, there are also clear differences between MPa and MPb: (i) the stability of the tonus finalis in $\mathrm{MPb}$ (always ending on the tonal center $^{19}$ ), which stands in contrast to the variability of the ending of MPa (on either the I-, II-, III- or V-scale degree); (ii) the preference for an arch-shaped pitch contour in $\mathrm{MPb}$, which contrasts with the mainly descending (alternatively, horizontal or U-form-like) profiles; and

16 It should be noted that in the case of the improvised poetry a s'arrepentina, like in similar genres in Sardinia, the rhythmic and melodic profiles of the final lines exhibit peculiar features compared to non-final lines. This is the reason why they were excluded from the present study, together with a meager number of (half)lines (or rather sketches thereof) that are manifestly related to the extemporary nature of poetry-making in this type of contest.

17 In ethnomusicological studies (see Kubik 1962, Knight 1974, Locke 1982, Stone 1985, Agawu 2006), it is quite common to refer to the basic rhythmic unit in music by using the term "pulse" as an equivalent of the more popular "beat". Likewise, the term "cycle" (see infra) is preferred in the literature over the more popular "bar" or "measure", whenever the latter is felt inadequate for the representation of metrical structure in oral forms of music and singing (for a critical discussion, see Arom 2005).

18 For an introduction and a critical discussion of the topic of segmentation within the musical field, see Fraisse 1974, Lerdahl \& Jackendoff 1983, Bent \& Drabkin 1990, Deutsch 1999, Baroni et al. 1999 and Müllensiefen 2010. References to the issue of segmentation within the field of Sardinian traditional song are found in Angeli 2006: 123-189, Macchiarella 2009: 187-212, Lutzu 2009: 49-65 and Bravi 2010: 392-401.

19 The concept of a "tonal centre", metaphorically denoted as a recognizable "center of gravity" in the organization of pitches in any piece of music, was developed in the field of ethnomusicology in order to avoid the implications of the word "tonic", which is definitely associated with the harmonic concepts of Western tonality (see Nettl 1964, Agamennone 1991). This concept is now currently in use in the field of music theory (see Lerdahl \& Jackendoff 1983, 2006, Doğantan-Dack 2013) to indicate a major point of attraction in music structure. 

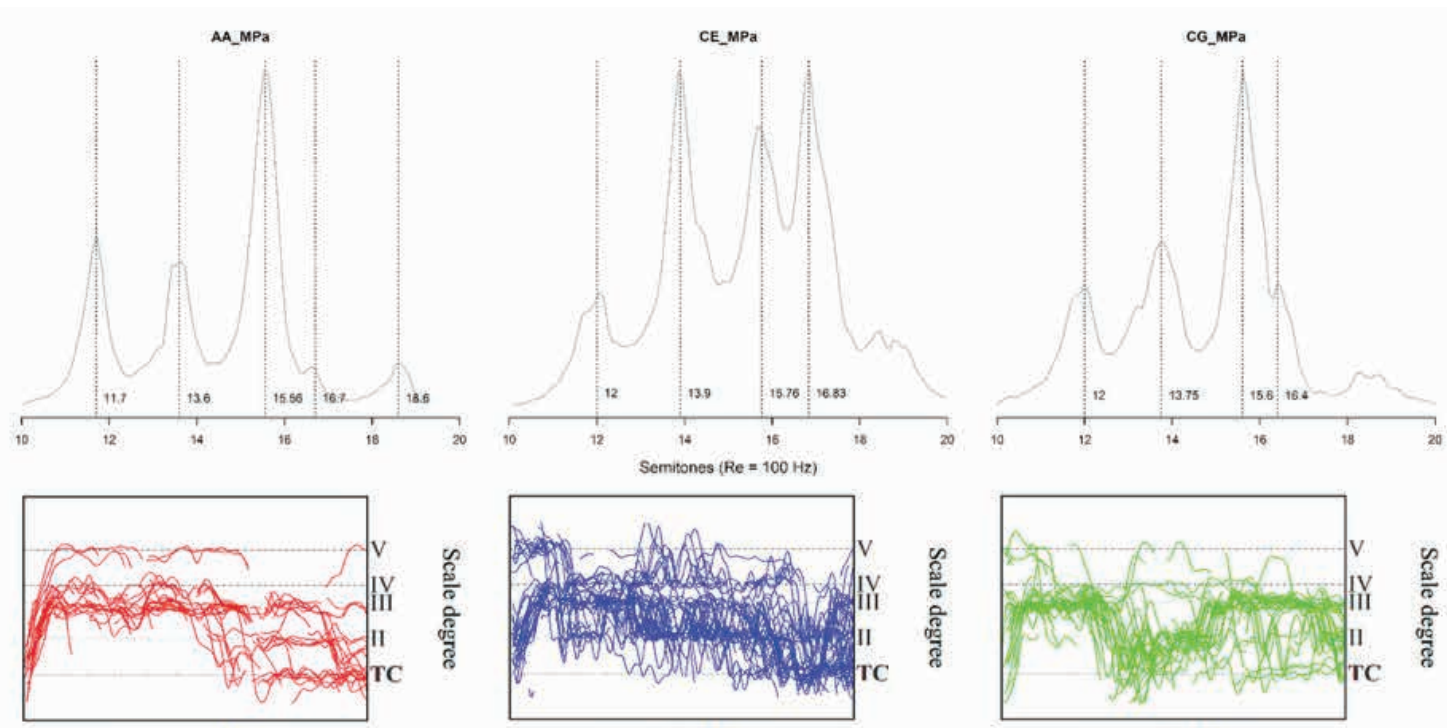

[normalized time]
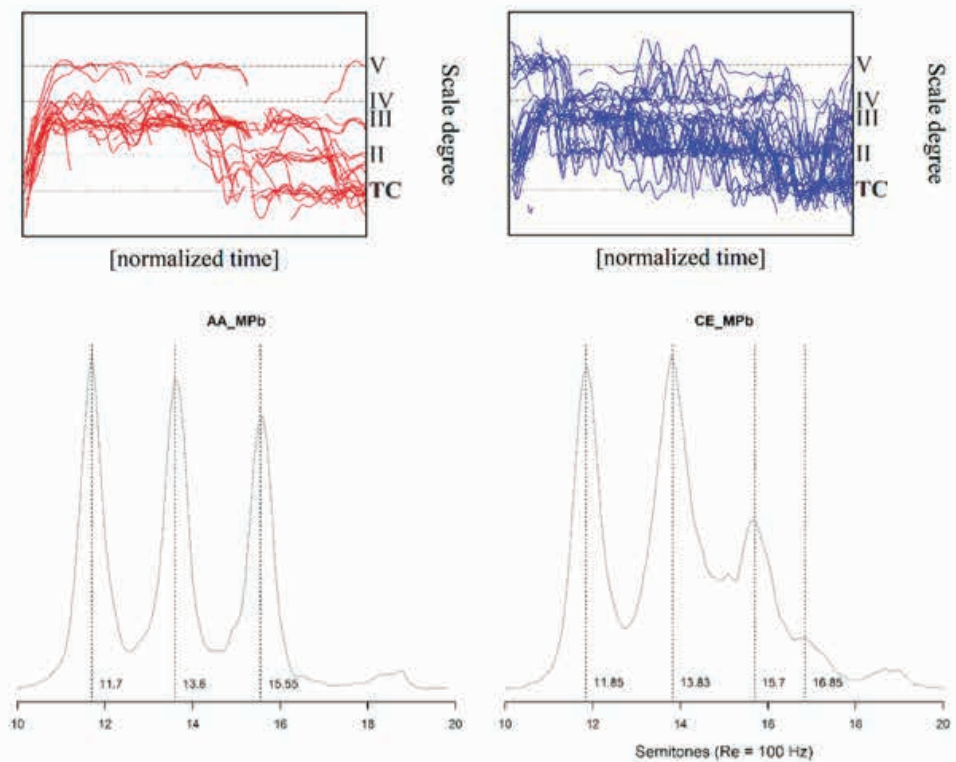

[normalized time]

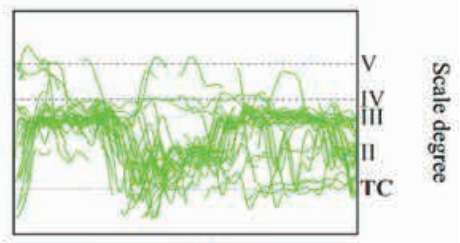

[normalized time]

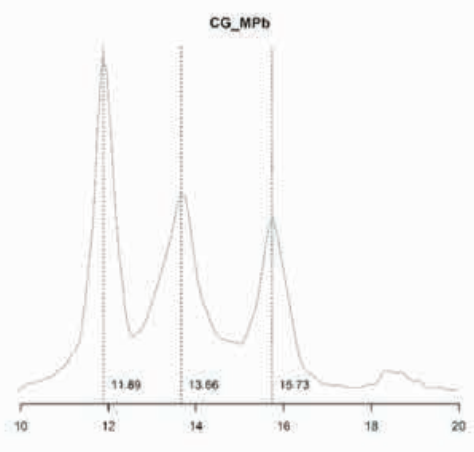

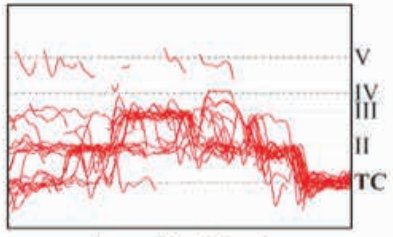

[normalized time]

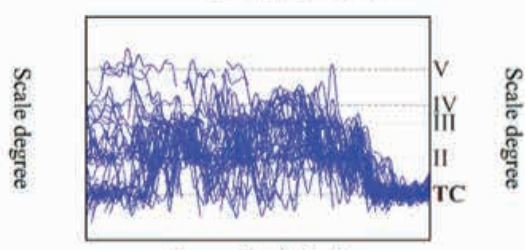

[normalized time]

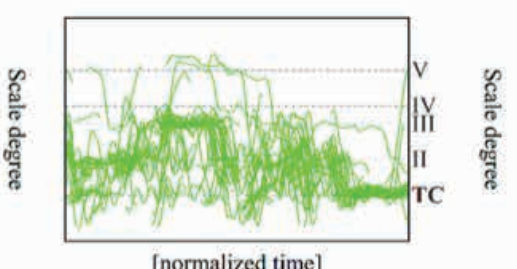

[normalized time]

Figure 6: Histograms of frequency and, below, corresponding pitch profiles, divided per poet (AA, CE and CG) and melodic phrase (MPa and $\mathrm{MPb}$ ). The $y$-axis graph of the pitch profiles indicates the tonal center (TC) and the scale degree of the major scale (i.e., with reference to the TC: II $=+2 \mathrm{st}$, III $=+4 \mathrm{st}, \mathrm{IV}=+5 \mathrm{st}, \mathrm{V}=+7 \mathrm{st}$ ).

finally, (iii) the use of the "tritonic" scale in the majority of MPb's, which, particularly in the case of CE, contrasts with the wider pitch range and high tones used in MPa's. From the inter-individual perspective, similarities and differences also appear in the styles of the three poets. Among them, (i) the melodic attack on the $\mathrm{V}$ degree in $\mathrm{MPa}$, followed by a rapid downward jump, is frequent in CE, but also appears in some cases in CG; (ii) the strong presence of the III degree in the MPa phrases of AA and CG, which appears as an initial corda di recita in the first of the two poets; and (iii) the different distribution among the poets of the three scale degrees in the MPb's, which are almost equally distributed in AA, whereas in CE we observe a lower frequency of the III degree, and in CG, dispreference for both II and III degrees.

As far as the "syntax" of the two melodic phrases is concerned, MPb can be repeated within one melodic line overarching two or even three verbal hemistichs, according to the basic rules expressed in (1), (2), and (3) below:

(1) One melodic line may comprise up to three MP's 

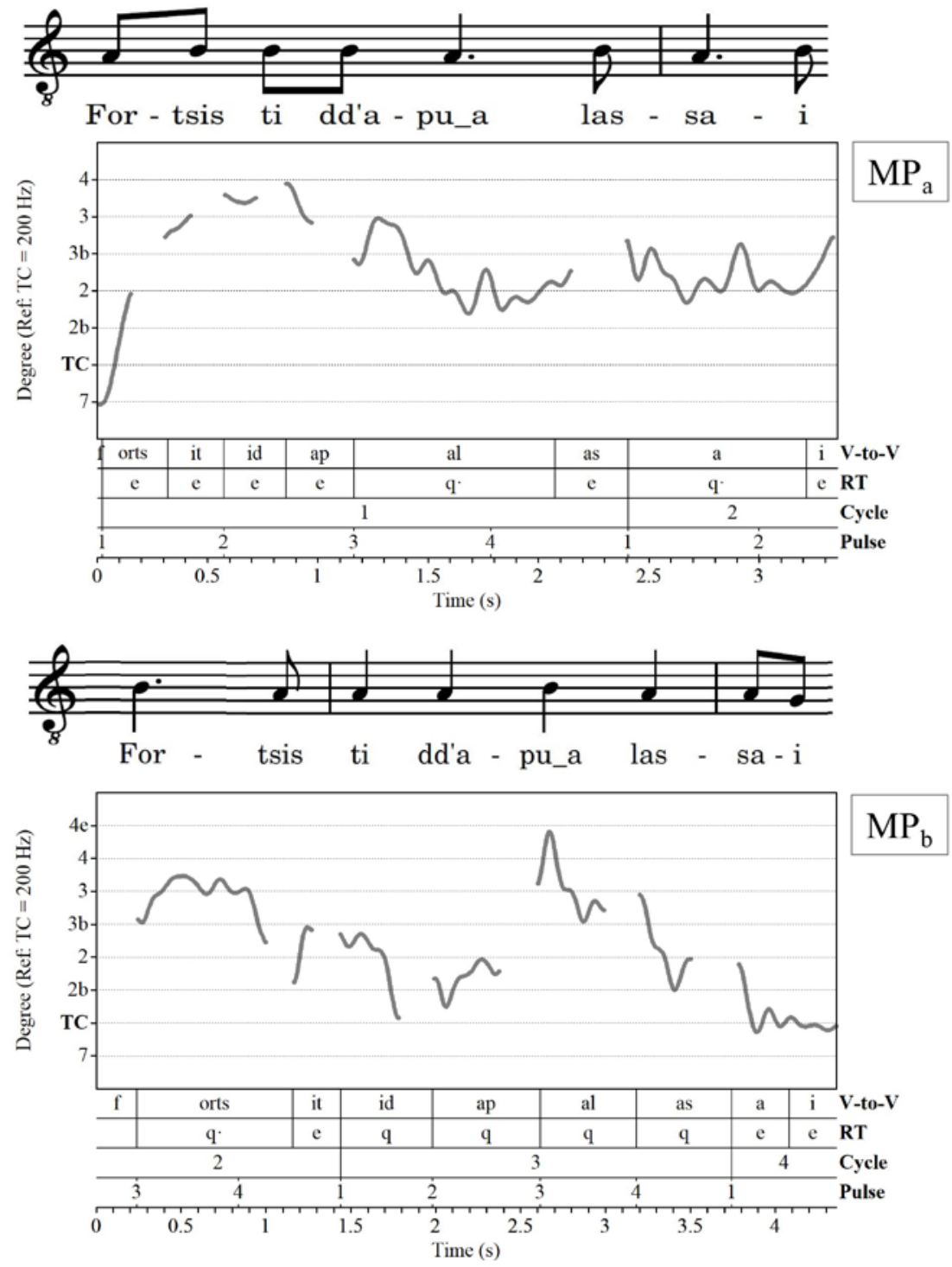

Figure 7: An illustration of MPa (top panel) and MPb (bottom panel). Both MP's are taken from the first line of Efisio Caddeo's second APF. Each MP is represented by both a standard musical score, including the lyrics, and the corresponding Praat pitch contour. The labels on the $y$-axis relevant to the pitch graph indicate the tonal center and distance from it expressed in terms of the standard music system (in particular: $b=$ minor interval, $e=$ exceeding interval; examples: $2 \mathrm{~b}=$ minor second, $2=$ major second, $4 \mathrm{e}=$ exceeding fourth). The four-tier annotation under the pitch profiles show the transcription of the V-to-V intervals together with the relevant rhythmic values and the 4-pulse cycles wherein each melodic phrase is inscribed.

(2) MPa cannot be repeated twice in the same melodic line

(3) When a melodic line comprises more than one phrase, both phrases must be present, and MPa must precede $\mathrm{MPb}$

From the above-defined rules, the corollaries expressed in (4) to (6) are derived:

(1) When a melodic line comprises a single MP, this may be either MPa or MPb

(2) When a melodic line comprises a sequence of two MP's, the sequence is necessarily $\mathrm{MPa} \gg \mathrm{MPb}$

(3) When a melodic line comprises a sequence of three MP's, the sequence is necessarily $\mathrm{MPa} \gg \mathrm{MPb} \gg>$ $\mathrm{MPb}$ 
The examination of the nine arrepentina turns (APF) occurring within the tema section reveals that, in fact, the first turn of each poet is based exclusively on the metrical scheme currentina (which does not have internal rhyme), whereas the remaining two are of a mixed type, each being made up of an initial part of AMS plus a coda in the currentina scheme.

In Fig. 8, the alignment between verbal halflines and melodic phrases is represented in the nine turns occurring within the tema section of the contest. Dark gray circles correspond to MPa and light gray circles correspond to $\mathrm{MPb}$. The numbers 1 and 2 inside the circles correspond to the $\mathrm{HL}_{1}$ and $\mathrm{HL}_{2}$, respectively. Barred circles correspond to lines construed on the currentina scheme, while non-barred circles correspond to lines based on the metrical scheme of arrepentina proper (AMS). In the first turn of each poet (i.e. AA1 - CE1 - CG1), where the caesura between the two verbal hemistichs is only virtual, insofar as there is no
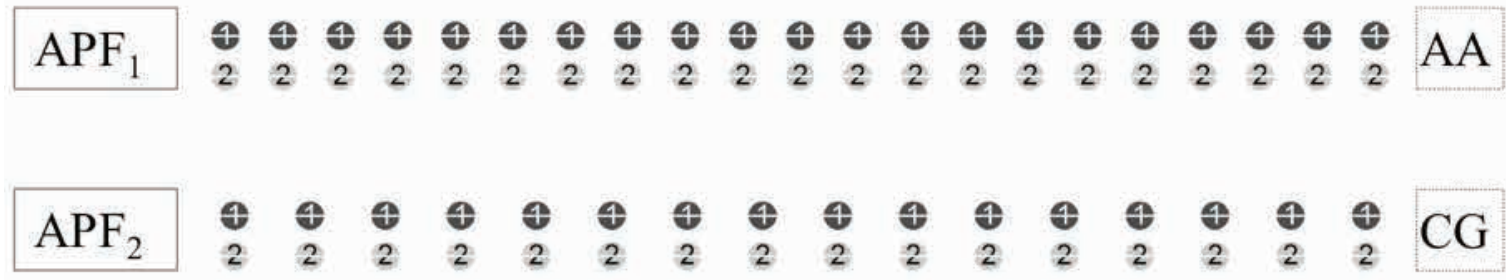

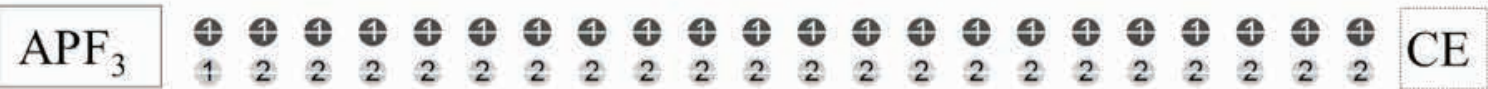

\begin{tabular}{|c|c|}
\hline $\mathrm{APF}_{4}$ & 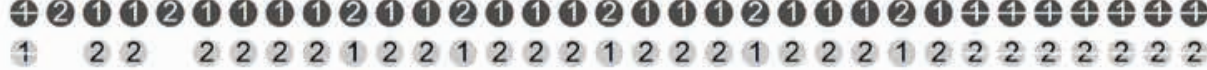 \\
\hline
\end{tabular}

$\mathrm{APF}_{5}$ क $\begin{array}{lllllllllllllllllllllllllll}1 & 2 & 2 & 2 & 2 & 2 & 2 & 2 & 2 & 2 & 2 & 2 & 2 & 2 & 2 & 2 & 2 & 2 & 1 & 2 & 2 & 2 & 2 & 2 & 2 & 2 & 2\end{array}$ 2110

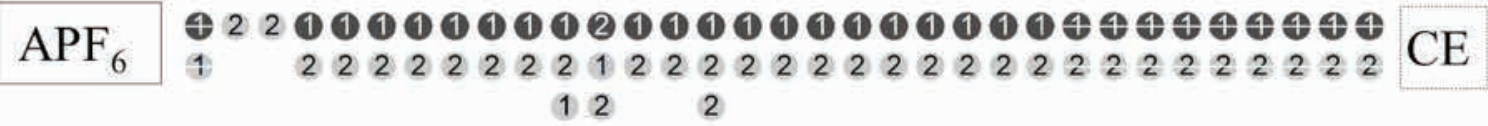

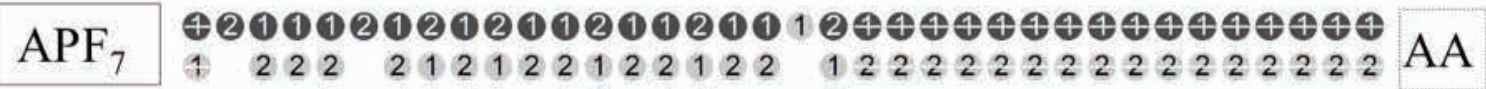
$\begin{array}{llllllllll}1 & 1 & 2 & 1 & 2 & 1 & 2 & 1 & 2 & 2\end{array}$

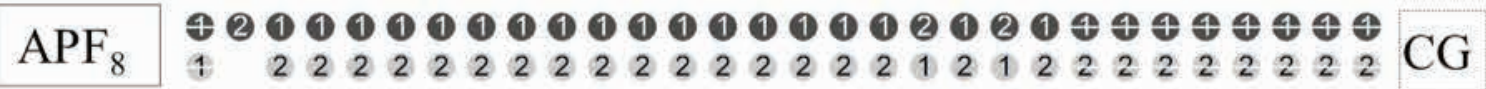
$2 \quad \begin{array}{lllllllll}1 & 2 & 1 & 2 & 1\end{array}$

\section{$\mathrm{APF}_{9}$


internal rhyme obligation, the musical setting is fixed. In fact, each verbal line corresponds to a melodic line of one kind: barred (= currentina), each MP being coextensive with either $\mathrm{HL}_{1}$ or $\mathrm{HL}_{2}$.

The remaining six turns offer a different picture. If we focus on the currentina codas (on the right-hand side of the diagram), we notice that there, too, the musical setting is fixed: each verbal line corresponds to a melodic line of one kind. However, in the preceding parts, which correspond to the arrepentina-proper metrical scheme (AMS), a higher degree of variability is observed in the relation between verbal halflines and musical phrases.

We observe, in particular, that in the AMS as well as in the currentina parts of the poets CE and CG the most common setting is what may be called the "symmetric" structure - i.e. the consistent matching of $\mathrm{HL}_{1}$ with $\mathrm{MPa}$ and $\mathrm{HL}_{2}$ with $\mathrm{MPb}$, respectively. The third poet $\mathrm{AA}$ instead shows a strong individual preference for what we may term an "asymmetric" setting, in which a three-part melodic line is set to a two-part verbal line. Although present in all poets, this asymmetric setting is more significantly attested in the AMS section of the poet AA (six occurrences in CE, ten occurrences in CG, twenty-two out of forty-four pairings in AA; see Fig. 9).

We further observe that while in the symmetric settings, $\mathrm{HL}_{1}$ consistently matches $\mathrm{MPa}$ and $\mathrm{HL}_{2}$ is always paired with $\mathrm{MPb}$, in the asymmetric settings, this one-to-one correspondence may be disrupted. Take for instance APF8 (see Fig. 8). In the section immediately preceding the currentina coda, there are five asymmetric settings, including the sequence $\mathrm{HL}_{121}\left|\mathrm{HL}_{212}\right| \mathrm{HL}_{121}\left|\mathrm{HL}_{212}\right| \mathrm{HL}_{121}$. When we look at the corresponding melody, we see that it consists of the repetition of the same compound melodic line, namely comprised of one MPa (dark gray circle) followed by two MPb's (light gray circles). Because these are all tripartite structures (in the verbal as well as the musical sequences), and because only $\mathrm{MPb}$ is allowed to occur twice within the same melodic line (according to rule (6) above), the result is a concatenation of sung lines starting alternatively with MPa and MPb where the melody straddles the boundaries of the verbal halflines.

\section{Microvariation: Rhythmic pulse and metrical positions}

At the level of the pairing of metrical positions and rhythmical values, some variation also emerges, either as the expression of an idiosyncrasy of the poet or as characteristic of specific locations in the sung line. The typical, recurring elements in the rhythmic makeup of the MP's are as follows: 1) the prevalence of pairs of eighth notes ( $e$ in our notation) at the beginning of $\mathrm{MPa}$, and 2) the occurrence of eighth notes at the end of $\mathrm{MPb}$. These elements are well attested in the performance of all three poets.

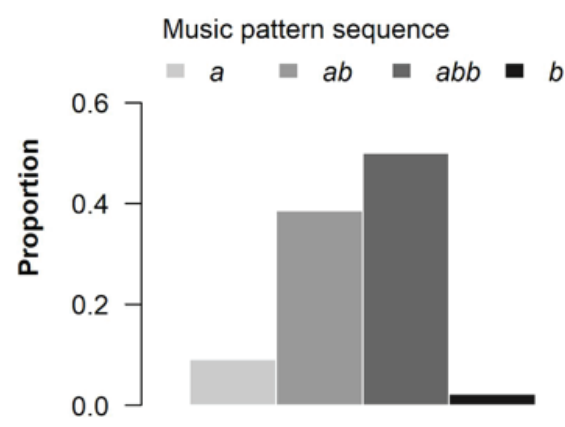

AA

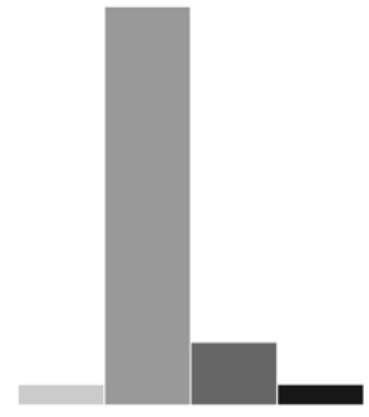

CE

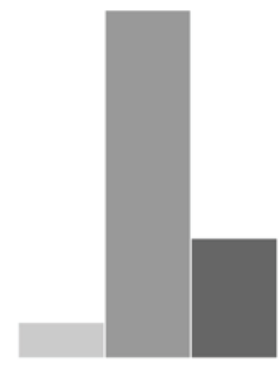

CG

Poet

Figure 9: Overall counts of simple and compound melodic lines (including up to three MP's) per poet. 

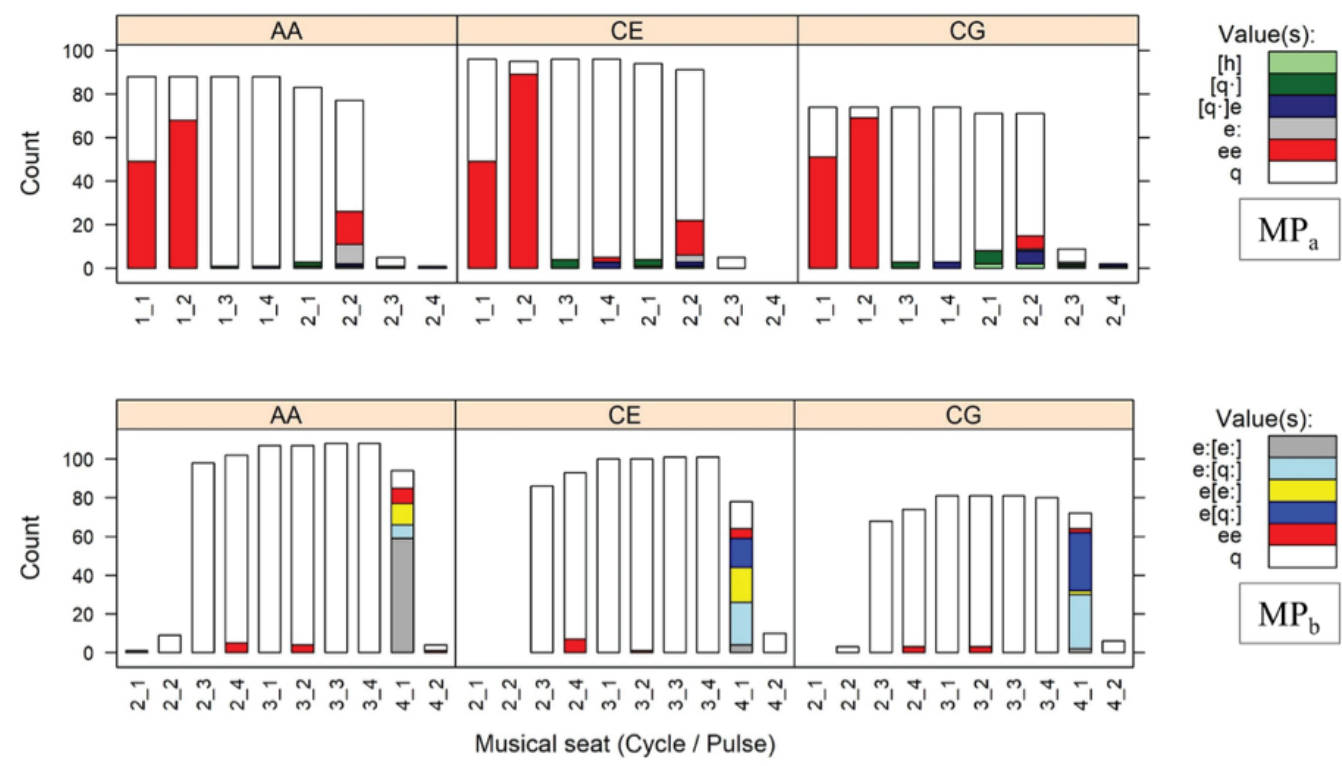

Figure 10: Distribution of rhythmical values per cycle and pulses for each poet. Values exceeding either to the left (i.e. starting in the preceding pulse) or to the right (i.e. ending in the following pulse) are in square brackets ([]). Rhythmic values for MPa are displayed in the top panel, those for MPb in the bottom panel (values with frequency rank $>7$ are excluded).

The inner part of the melodic line is characterized by the general principle "one beat-one event" ${ }^{20} \mathrm{~A}$ frequency distribution (see Fig. 10) shows that violations of this principle occur both in $\mathrm{MPa}$ and $\mathrm{MPb}$ in positions corresponding to the weak beats of the musical structure (i.e. each cycle/pulse ending in either 2 or 4, as in 1_2, 1_4, 2_2, etc.). These violations result in the diminished role, in the rhythmic profile of each MP, assigned to the $q$ value, which is replaced by shorter values, such as the rhythmical figures $e e$, or $[q] \cdot e$ in place of $q q$. While in the strong beats (e.g. 1_1, 1_3,2_1,2_3, etc.) the $q$ value is generally maintained, in the intervening weak beats, this is not the case. These violations, in fact, come about only at 1_4 and 2_1 in $\mathrm{MPa}$, and 2_4 and 3_2 in MPb. ${ }^{21}$

Regarding MPa, there are furthermore significant differences in the distribution of the pair $q \mid e e$ in the first two beats of cycle 1 . In particular, the subdivision of $q$ into ee in 1_1, i.e. the first beat of the first cycle, is observed with higher frequency in CG than in the other two poets, with AA being the least inclined to use it. $^{22}$

The different distribution of the basic rhythmical structures among the halflines (and the poets) correlates with another kind of variation, which is observed when looking at the verbal halflines independently of their melodic settings. We notice that $\mathrm{HL}_{2}$ has a tendency to be hypermetrical, i.e. to add one or two extra positions to the canonical eight positions, considered the putative model of AMS in traditional accounts (see section 1 above). Conversely, in $\mathrm{HL}_{1}$, it is not uncommon to have seven or - to a lesser extent - even six positions. In particular, AA shows a greater preference for the six-position $\mathrm{HL}_{1}$ than his two colleagues. $\mathrm{CE}$, on the other hand, uses the seven-position $\mathrm{HL}_{1}$ almost as much as the eight-position $\mathrm{HL}_{1}$. This variation in length between the two hemistichs could possibly be associated with the dispreference AA shows for the rhythmical subdivision of the rhythmic group $q q$ in the first two beats of cycle 1.

20 As already anticipated, this principle is quite regularly disregarded at the fringes of the sung phrases, i.e. in positions corresponding to the beats referred to here as $1 \_1$ and 1_2 in MPa and as 4_1 in MPb.

21 As a side note, it is noteworthy that no rhythmic subdivision ever occurs in 3_4. While representing a weak beat in terms of musical rhythm, 3_4 also immediately preceds the right-hand edge of the line, which is usually characterized by values shorter than $q$. The rhythmic regularity at this location may be regarded as a means to further underline the imminent closure of the line.

22 Statistics: $X$-squared $=5.7083, \mathrm{df}=2, \mathrm{p}$-value $=0.05761$ (pulse 1_1); X-squared $=14.358, \mathrm{df}=2, \mathrm{p}$-value $=0.0007626($ pulse 1_2). 


\section{Conclusion: From variation to style}

The approach taken here has allowed us to discover some significant variants in the singing of the arrepentina lines, which might ultimately be considered marks of individual poetic styles.

The parallel analysis of the melodic line, on the one hand, and the verbal line, on the other, has allowed us to separate these two levels, which are inextricably intertwined in the performance.

After breaking down the verbal as well as the musical lines into smaller constituents - namely $\mathrm{HL}_{1,2}$ for the text, MPa,b for the melody - we examined the way HL's and MP's are paired in singing. By doing so, we were able to identify one source of variation, what we called the "asymmetric setting". We were also able to establish the frequency with which this specific setting is employed by the three poets. From this investigation, it emerged that poet AA uses it as much as the symmetric setting, whereas the other two employ it only sporadically.

Further, the rhythmic makeup of MPa,b was closely examined. The main difference was found to lie in the location of pairs of short (eighth) notes: at the beginning for MPa, at the end for MPb. Regarding MPa, the analysis further revealed significant inter-individual variation when it comes to the distribution of the rhythmic group $q \mid e e$ in the first two beats of cycle 1. In particular, the subdivision of $q$ into ee in the first beat of the first cycle was observed with the least frequency in AA and with the highest frequency in CG.

The results of our investigation are compatible with the analyses carried out by our predecessors. In fact, most of the halflines appear to be based on an eight-position meter. However, a significant difference is observed between the two hemistichs, specifically in relation to the melody they are set to. In particular, our analysis emphasizes that it is the disruption of the one-to-one correspondence between musical notes in the MP and metrical positions in the HL that is responsible for the variation in the number of syllables per hemistich. This variation, which amounts to one or two missing syllables in $\mathrm{HL}_{1}$ and to one or two extra syllables in $\mathrm{HL}_{2}$, originates at specific weak locations in the melodic line.

To conclude, our approach enabled us to demonstrate that variation in the Sardinian arrepentina (and potentially in other similar genres) results not only from an intrinsic tension in the makeup and alignment of textual and musical constituents, but also in clear-cut differences among the poets as far as the specific types of preferred settings are concerned. In the same spirit as Kiparsky (1977: 245), we would like to emphasize that variation within a specific poetic tradition has nothing arbitrary to it. Instead, it is "a wellbehaved progression" along specific dimensions, which for sung extemporary poetry are to be identified individually in both the linguistic and musical domains, as well as in the alignment of text and music.

Although each of the aspects presented here deserves further analysis (on a broader corpus), the proposed methodology succeeds in relating stylistic variation to general mechanisms that can and should be made explicit, if one wants to reconcile the diversity of rhythmical patterns and line lengths observed in sung poetry with the idea of a common template underlying them.

ACKNOWLEDGMENTS: We wish to thank the poets Alberto Atzori, Efisio Caddeo, Giuseppe Caddeu and the accordionist Gianfranco Massa for their kind permission to make the recordings and for their contribution to this research. We are grateful to Ignazio Murru, Marco Lutzu, Ignazio Macchiarella and the entire research group responsible for the SardinianOralPoetry project for allowing us to use the recordings and for their friendly support and advice.

\section{References}

Adamo, Giorgio. 1994. Metrica cantata, metrica recitata (Sung Metrics, Recited Metrics). In: Bravi, Paolo, Francesco Giannattasio, Adelaide Pescatori (eds.), Il verso cantato. Atti del Seminario di studi (Aprile-Giugno 1988) (Sung Verse. Proceedings of the Study Seminar April-June 1988), 55-68. Roma: Università degli Studi di Roma La Sapienza. Agamennone, Maurizio. 1991. Modalità / Tonalità (Modality / Tonality). In: Agamennone, Maurizio, Serena Facci, Francesco Giannattasio, Giovanni Giuriati (eds.), Grammatica della musica etnica (Grammar of ethnic music), 145-200. Roma: Bulzoni. 
Agawu, Kofi. 2006. Structural Analysis or Cultural Analysis? Competing Perspectives on the 'Standard Pattern' of West African Rhythm. Journal of the American Musicological Society 59(1). 1-46.

Angeli, Paolo. 2006. Canto in Re. La Gara a Chitarra nella Sardegna settentrionale (Song in Re. The Gara a chitarra in Northern Sardinia). Nuoro: ISRE.

Arom, Simha. 2005. L'organizzazione del tempo musicale. Saggio di una tipologia (The organization of musical time. Essay of a typology). In Enciclopedia della musica, vol. 5: L'unità della musica (Encyclopedia of Music, vol. 5: The Unity of Music), 1087-1103.Torino: Einaudi.

Barbosa, Plínio A., Pablo Arantes, Alexsandro R. Meireles, Jussara M. Vieira. 2005. Abstractness in Speech-Metronome Synchronisation: P-Centres as Cyclic Attractors. In: INTERSPEECH 2005, 1441-1444.

Baroni, Mario, Rossana Dalmonte, Carlo Jacoboni. 1999. Le regole della musica. Indagine sui meccanismi della comunicazione. (Musical rules. Investigation on the mechanisms of communication). Torino: EDT.

Beltrami, Pietro G. 1991. La metrica italiana (Italian Metrics). Bologna: Il Mulino.

Bent, Ian, William Drabkin. 1990. Analisi musicale (Musical Analysis). Torino: EDT.

Boersma, Paul, David Weenink. Praat: doing phonetics by computer. 1992-2018. http://www.fon.hum.uva.nl/praat/ (accessed 04 01, 2018).

Brăiloiu, Constantin. 1982. Folklore musicale (Musical Folklore). Vol. 2. Roma: Bulzoni.

Bravi, Paolo. 2010. A sa moda campidanesa. Pratiche, poetiche e voci degli improvvisatori nella Sardegna meridionale (In the Campidanese Way. Behaviours, Poetics and Voices of Improvisers in Southern Sardinia). Nuoro: ISRE.

Bravi, Paolo. 2012a. Il canto a chitarra nella Sardegna meridionale (Song accompanied by Guitar in Southern Sardinia). In: Carboni, Salvatore, Paolo Bravi (eds.), Enciclopedia della musica sarda - Vol. 5 (Encyclopedia of Sardinian Music - Vol. 5), 114-139. Cagliari: Unione Sarda.

Bravi, Paolo. 2012b. La musica de s'arrepentina (Music in s'arrepentina). In: Zedda, Paolo (ed.), Enciclopedia della musica sarda - Vol. 14 (Encyclopedia of Sardinian Music - Vol. 14), 160-163. Cagliari: Unione Sarda.

Bravi, Paolo. 2015. Sung Syllables. Structure and Boundaries of the Metrical Unit in Sung Verse. In Russo, Domenico (ed.), The Notion of Syllable across History, Theories and Analysis, 436-452. Cambridge: Cambridge Scholar Publishings.

Bravi, Paolo, Teresa Proto. (submitted for publication). Epistemologia del verso cantato: il caso dell'arrepentina della Sardegna centro-meridionale. In: Proto, Teresa, Paolo Bravi (eds.), [Title to be defined]. Udine: Nota

Cirese, Alberto M., Aristide Murru, Paolo Zedda. 2006. Unu de Danimarca benit a carculai. Il mondo poetico di Ortacesus nelle registrazioni e negli studi di Andreas Fridolin Weis Bentzon tra il 1957 e il 1962 (One from Denmark comes to appreciate. The poetic world of Ortacesus in the recordings and studies of Andreas Fridolin Weis Bentzon between 1957 and 1962). Cagliari: Iscandula.

Contini, Michel. 1987. Etude de géographie phonétique et de phonétique instrumental du sarde (Study of Phonetic Geography and Instrumental Phonetics of Sardinian). Alessandria: Dell'Orso.

Cornulier (de), Benoît. 2000. Sul legame del ritmo e delle parole in alcune formule di canti tradizionali. Nozioni di ritmica orale (On the connection of rhythm and words in some formulas of traditional songs. Notions of oral rhythm). Studi di Estetica 21. 41-63.

Deutsch, Diana. 1999. Grouping Mechanisms in Music. In: Deutsch, Diana (ed.), The Psychology of Music, 299-348. San Diego: Academic Press.

Di Girolamo, Costanzo. 1976. Teoria e prassi della versificazione (Theory and practice of versification). Bologna: Il Mulino.

Diaz-Pimienta, Alexis. 1998. Teoría de la improvisación. Primeras páginas para el estudio del repentismo (Theory of Improvisation. First Pages for the Study of the Repentismo). Oiartzun (Gipuzkoa): Auspoa-Sendoa.

Doğantan-Dack, Mine. 2013. Tonality: The Shape of Affect. Empirical Musicology Review 8/3-4. 208-218.

Elwert, Wilhelm Theodor. 1987. Versificazione italiana dalle origini ai giorni nostri (Italian versification from its origins to the present day). Firenze: Le Monnier.

Fabb, Nigel. 2002. Language and Literary Structure. The Linguistic Analysis of Form in Verse and Narrative. Cambridge: CUP. Fadda Pischedda, Francesco. 1895. Raccolta di scelte poesie popolari sarde alla campidanese o cagliaritana in vario metro con l'aggiunta di diverse poesie logudoresi (Collection of selected Sardinian folk poems in Campidanese or Cagliari dialect in various meter with the addition of several Logudorese poems). Cagliari: Tipografia del Corriere.

Farnetani, Edda, Shiro Kori. 1986. Effects of Syllable and Word Structure on Segmental duration in Spoken Italian. Speech Communication 5. 17-34.

Fraisse, Paul. 1974. Psychologie du ritme (Psychology of rhythm). Paris: Presses Universitaires de France.

Garzia, Raffaele. 1916. Ritmica sarda (Sardinian Rhytmics). In Boullier, Auguste (ed.), Canti popolari della Sardegna

(Folksongs of Sardinia), 197-222. Bologna: [s.n.]

Ghiani, Fiorenzo. 1994a. I dodici poeti terralbesi dell'“Accademia” della Repentina (The twelve Terralbese poets of the "Accademia" of Repentina). Terralba leri\&Oggi. 44-46.

Ghiani, Fiorenzo. 1994b. L'“Accademia” della Ripentina (The "Accademia" of Ripentina). Terralba leri\&Oggi. 18-20.

Halle, Morris, Samuel Jay Keyser. 1966. Chaucher and the Study of Prosody. College English XXVIII. 187-219.

Janker, Peter M. 1996. Evidence for the p-center syllable-nucleus-onset correspondence. ZASPiL 7. 94-124.

Kiparsky, Paul. 1977. The Rhythmic Structure of English Verse. Linguistic Inquiry 8. 189-247.

Knight, Roderic. 1974. Mandinka Drumming. African Arts 7 (4). 25-35. 
Kubik, Gerhard. 1962. The Phenomenon of Inherent Rhythms in East and Central African Instrumental Music. African music 3 (1). 33-42.

Lerdahl, Fred, Ray Jackendoff. 1983. A Generative Theory of Tonal Music. Cambridge (MA): MIT Press.

Lerdahl, Fred, Ray Jackendoff. 2006. The Capacity for Music: What Is It, and What's Special about it. Cognition 100. 33-72.

List, George. 1974. The reliability of transcription. Ethnomusicology 18 (3). 353-377.

Locke, David. 1982. Principles of Offbeat Timing and Cross-Rhythm in Southern Eve Dance Drumming. Ethnomusicology 26 (2). 217-246.

Lutzu, Marco. 2007. Forme e struttura della gara poetica a sa repentina (Form and Structure in the Poetry Contest a sa repentina). In: Su cantu de sei in Sardinnia (Improvised poetry in Sardinia), 7-25. Quartu S. Elena (CA): Alfa.

Lutzu, Marco. 2009. Sa Passione. La riscoperta del canto a Nughedu San Nicolò [CD book] (Passion. The Rediscovery of Singing in Nughedu San Nicolò [CD book]). Cagliari: Live Studio.

Lutzu, Marco, Ignazio Murru. 2012. La tradizione poetica de s'arrepentina (The Poetic Tradition of s'arrepentina). In: Zedda, Paolo (ed.), Enciclopedia della musica sarda - Vol. 14 (Encyclopedia of Sardinian Music - Vol. 14), 152-171. Cagliari: Unione Sarda.

Macchiarella, Ignazio. 2009. Cantare a cuncordu. Uno studio a più voci (Singing a cuncordu. A multipart study). Udine: Nota.

Madau, Matteo. 1997 ed. or. 1787. Le armonie de' Sardi (Harmonies of Sardinians). Orig.: Cagliari, Stamperia Reale. Lavinio, Cristina (ed.) Nuoro: Ilisso.

Masili, Ezelinu. 1995. Sa Musa paesana (The Village Muse). San Gavino (CA): Fiore.

Müllensiefen, Daniel. 2010. Statistical techniques in music psychology: an update. In: Bader, Rolf, Christiane Neuhaus, Ulrich Morgenstern (eds.), Concepts, Experiments, and Fieldwork: Studies in Systematic Musicology and Ethnomusicology, 193-215. Frankfurt am Main: Peter Lang.

Murgia, Ivo. 2012. La lingua de s'arrepentina (The Language of s'arrepentina). In: Zedda, Paolo (ed.), Enciclopedia della musica sarda - Vol. 14 (Encyclopedia of Sardinian Music - Vol. 14), 172-173. Cagliari: Unione Sarda.

Murru, Ignazio. 2010. Sa Repentina. Il dono del poetare: la tradizione e l'istruzione (Sa Repentina. The Gift of Making Poetry: Tradition and Education). Master Degree Thesis. Cagliari (IT): Conservatorio di Musica di Cagliari.

Nettl, Bruno. 1964. Theory and Method in Ethnomusicology. Glencoe: Free Press.

Onnis, Faustino. 1997. Sa scola de cantu repentinu terrabesu (The School of Repentina Poetry of Terralba). Terralba leri \& Oggi. 36-37.

Pettorino, Massimo, Elisa Pellegrino, Marta Maffia. 2015. From Syllables to VtoV: Some Remarks on the Rhythmic Classification of Languages. In: Russo, Domenico (ed.), The Notion of Syllable across History, Theories and Analysis, 417-435. Cambridge: Cambridge Scholars Publishing.

Pillai, Carlo. 1985. Le canzoni degli improvvisatori: fonti per la storia locale? (Improvisers' songs: Sources for Local History?). In: Bertolucci, Paola, Rino Pensato (eds.), La memoria lunga. Le raccolte di storia locale dall'erudizione alla documentazione, Atti del Convegno Cagliari, 28-30 aprile 1984 (The Long Memory. Collections of Local History from Erudition to Documentation, Proceedings of the Conference held at Cagliari, 28-30 April 1984), 311-329. Milano: Bibligrafica.

Piras, Guglielmo. 2012. Un verso antico: il doppio senario (An Ancient Line: the Double Senario). In: Carboni, Salvatore, Paolo Bravi (eds.), Enciclopedia della musica sarda - Vol. 5 (Encyclopedia of Sardinian Music - Vol. 5), 150-151. Cagliari: Unione Sarda.

Porcu, Giancarlo. 2008. Régula castigliana. Poesia sarda e metrica spagnola dal '500 al '700 (Castilian Régula. Sardinian poetry and Spanish metrics from the 1500 s to the 700 s). Nuoro: Il Maestrale.

Puddu, Mario. 2008. Revisione ortogràfica de is testus (Orthographic Revision of texts). In: Rossi, Nicoletta, Stefano Meloni (eds.), La tradizione poetica della provincia del Medio Campidano. Componimenti in lingua sarda (Poetic Tradition of the Province of Medio Campidano. Poems in Sardinian), 45-50. Dolianova (CA): Grafica del Parteolla.

Ramous, Mario. 1984. La metrica (Metrics). Milano: Garzanti.

Rossi, Nicoletta, Stefano Meloni. 2007. Passato e presente nella poesia marese. Composizioni in lingua sarda (Past and Present in the Poetry of Maracalagonis. Poems in Sardinian). Dolianova: Grafica del Parteolla.

Spano, Giovanni. 1840. Ortografia sarda nazionale (Sardinian National Orthography). Cagliari: Reale Stamperia.

Stone, Ruth M. 2005. Music in West Africa: experiencing music, expressing culture. Oxford: Oxford University Press.

Virdis, Maurizio. 1978. Fonetica del dialetto sardo campidanese (Phonetics of the Sardinian-Campidanese Dialect). Cagliari: Della Torre.

Zedda, Paolo, \& Antonio Pani. 2005. Sa cantada, I poeti improvvisatori (The poetry contest. The improvising poets). Quartu S. Elena (CA): Alfa. 